\title{
Resistance of Zwitterionic Peptide Monolayers to Biofouling
}

Thomas Ederth, Maria Lerm, Beatriz Orihuela and Daniel Rittschof

The self-archived postprint version of this journal article is available at Linköping University Institutional Repository (DiVA):

http:// urn.kb.se/ resolve?urn=urn:nbn:se:liu:diva-154665

N.B.: When citing this work, cite the original publication.

Ederth, T., Lerm, M., Orihuela, B., Rittschof, D., (2019), Resistance of Zwitterionic Peptide Monolayers to Biofouling, Langmuir, 35(5), 1818-1827. https:// doi.org/10.1021/acs.langmuir.8b01625

Original publication available at:

https:// doi.org/ 10.1021/ acs.langmuir.8b01625

Copyright: American Chemical Society

http:// pubs.acs.org/ 


\title{
The resistance of zwitterionic peptide monolayers to biofouling
}

\author{
Thomas Ederth $^{1, *}$, Maria Lerm ${ }^{2}$, Beatriz Orihuela ${ }^{3}$, Daniel Rittschof ${ }^{3}$ \\ ${ }^{1}$ Division of Molecular Physics, Department of Physics, Chemistry and Biology, Linköping \\ University, SE-581 83 Linköping, Sweden \\ ${ }^{2}$ Division of Microbiology and Molecular Medicine, Department of Clinical and \\ Experimental Medicine, Linköping University, SE-581 83 Linköping, Sweden \\ ${ }^{3}$ Duke University Marine Laboratory, Nicholas School of the Environment, Duke University, \\ Beaufort, North Carolina 28516-9721, USA
}

* Corresponding author: thomas.ederth@liu.se

\begin{abstract}
Self-assembled monolayers (SAMs) are widely used in science and engineering, and recent progress has demonstrated the utility of zwitterionic peptides with alternating lysine (K) and glutamic acid (E) residues for antifouling purposes. Aiming at developing a peptide-based fouling-resistant SAM suitable for presentation of surface-attached pheromones for barnacle larvae, we have investigated five different peptide SAMs, where four are based on the EK motif, and the fifth was designed based on general principles for fouling resistance. The SAMs were formed by self-assembly onto gold substrates via cysteine residues on the peptides, and formation of SAMs was verified via ellipsometry, wettability, infrared reflection-absorption spectroscopy and cyclic voltammetry. Settlement of cypris larvae of the barnacle Balanus (=Amphibalanus) amphitrite, the target of pheromone studies, was tested. SAMs were also subjected to fouling assays using protein solutions, blood serum, and the bacterium Mycobacterium marinum. The results confirm the favourable antifouling properties of EK-containing peptides in most of the assays, although this did not apply to the barnacle larvae settlement test, where settlement was low on only one of the peptide SAMs. The one peptide that had antifouling properties for barnacles did not contain a pheromone motif, and would not be susceptible to degredation by common serine proteases. We conclude that the otherwise broadly effective antifouling properties of EK-containing peptide SAMs is not directly applicable to barnacles, and that great care must be exercised in the design of peptidebased SAMs for presentation of barnacle-specific ligands.
\end{abstract}




\section{Introduction}

Surfaces or coatings which effectively prevent adsorption of biological material are needed in many areas of science and engineering, for example, for efficient operation of biosensors, for biocompatibility of implants and biomedical equipment, to prevent macrophage uptake of drug delivery vehicles, to minimize biofilm formation during food processing, or to reduce drag on ship hulls. Considerable efforts have been devoted to the design of such materials, and the chemical and structural versatility of polymers have made these common as antifouling coatings. ${ }^{1-3}$ For many purposes, in particular in biomaterials and biosensing, poly(ethylene glycol) (PEG) is an important candidate for such coatings ${ }^{4}$, but also oligo(ethylene glycol) (OEG)-modification of surfaces, with sometimes very few monomer units, have been found very effective in this regard, for examples as end-functionalization of self-assembled monolayers (SAMs). ${ }^{5-6}$

PEG and OEG coatings effectively prevent protein adsorption, but are also associated with problems, such as oxidative degradation, immunogenicity, and poor water solubility and protein resistance at elevated temperatures. This has stimulated research in alternatives, with the aim to retain the excellent antifouling properties of PEG, while improving chemical and mechanical stability. It is generally accepted that strong hydration is an important factor for the antifouling properties of PEG, which has a large dipole moment rendering the chain a strong hydrogen-bond acceptor. ${ }^{4,6}$ Charge-balanced materials, such as zwitterionic polymers, ${ }^{7-9}$ have emerged as interesting alternative candidates for antifouling coatings, since zwitterions can potentially form a more strongly bound hydration layer via electrostatic interactions, while still retaining overall charge neutrality. In polymers and SAMs, this can be accomplished either by inclusion of zwitterionic groups (carboxybetaine, sulfobetaine, phosphorylcholine etc.) or by mixing anionic and cationic residues, to form a pseudozwitterionic (or polyampholytic) coating. Early examples of (pseudo)zwitterionic SAMs includes quaternary ammonium, sulfonate and phosphate residues ${ }^{10}$, and phosphorylcholine ${ }^{11}$, and several other works, using a variety of zwitterionic SAMs, have followed. ${ }^{12-15}$

Considered as materials, peptides are polymers with the advantages of well-developed and highly controlled preparation methods, a range of natural and synthetic amino acids for tuning the properties of the peptides, biodegradability, and often high biocompatibility. ${ }^{16-18}$ These advantages have been exploited for engineering of interfaces via surface attachment of peptides, for example in the preparation of model systems in surface science ${ }^{19}$, for functionalization of implants ${ }^{20}$, biosensor development ${ }^{21}$, to explore surface interaction mechanisms in bioadhesion ${ }^{22}$ and also for general antifouling purposes. ${ }^{23-26}$ Among the antifouling peptides, varieties featuring repeated glutamic acid and lysine (EK) motifs have attracted particular attention. ${ }^{23,27-29}$

For biosensing, or other applications where specific interactions with ligands exposed on a surface are desired, the presentation of the ligand is often critical, with surface density and steric availability being of particular importance, in addition to the requirement that the ligands are presented against a fouling-resistant background which does not induce nonspecific adsorption or other undesired reactions. Such systems are often designed using mixed SAMs prepared from differently $\omega$-functionalized alkanethiols. ${ }^{30}$ However, where the ligands are peptides, there might be advantages in preparing the SAM from differently end- 
functionalized peptides instead. The possibilities to control interface composition are vast for both types of SAMs, though model systems for biomolecular interactions based on alkylthiol SAMs are more commonly used in studies of interface structure-function relationships. ${ }^{30}$ An important reason for this is that peptide SAMs, as opposed to, for example, peptideterminated alkylthiol SAMs, are qualitatively very different, in that the absence of the alkyl chain makes the SAMs less stable, and more sensitive to environmental changes.

With a view to providing a peptide-based fouling-resistant SAM suitable for subsequent presentation of surface-attached pheromones, we have investigated the fouling resistance of five zwitterionic peptide SAMs, where four are based on the EK motif, and the fifth was designed based on general principles for fouling resistance. The SAMs were formed by selfassembly onto gold substrates via cysteine residues on the peptides. The physico-chemical properties of the SAMs were studied by contact angle measurements, ellipsometry, infrared spectroscopy and cyclic voltammetry. While our interest in biofouling is aimed at a general understanding at a fundamental level, a particular motivation for this work was to find a peptide SAM that is useful for presentation of pheromones hypothesized to affect the settlement of barnacle cypris larvae. Hence, this SAM must not induce settlement of cyprids, and an assay testing the settlement preferences of cypris larvae of the barnacle Balanus amphitrite onto the peptide SAMs is central for the work. Since the surface exposing the ligand must be resistant to fouling by macromolecules and/or bacteria present in the analyte, we have extended the antibiofouling tests to also include the resistance of the peptide SAMs to fouling from proteins in solution, from blood serum (as a model of a complex biofluid), and to the attachment of a bacterium, Mycobacterium marinum. The results are compared to those obtained on PEG- and methylated PEG-terminated alkylthiol SAMs (used also as negative controls), and on hydrophobic methyl-terminated SAMs (positive control).

\section{Materials and methods}

\section{Chemicals}

Peptides were obtained from GL Biochem (Shanghai, China), prepared to $>96 \%$ purity, and used as received. The methylated PEG thiol (HS- $\left.\left(\mathrm{CH}_{2}\right)_{11}-\mathrm{CONH}-\left(\mathrm{C}_{2} \mathrm{H}_{4} \mathrm{O}\right)_{11}-\mathrm{CH}_{3}, \mathbf{m P E G}\right)$ was obtained from Polypure (Oslo, Norway), the preparation of the PEG thiol (HS- $\left(\mathrm{CH}_{2}\right)_{15}$ $\mathrm{CONH}-\left(\mathrm{C}_{2} \mathrm{H}_{4} \mathrm{O}\right)_{6}-\mathrm{OH}$, referred to as $\left.\mathbf{E} \mathbf{G}_{6}\right)$ was described by Svedhem et al. ${ }^{31}$, and hexadecanethiol (HS- $\left.\left(\mathrm{CH}_{2}\right)_{16}-\mathrm{CH}_{3}, \mathrm{C}_{16}\right)$ obtained from Fluka. Ethanol was 99.5\% (Solveco, Stockholm), water was Milli-Q water (18.2 M $\Omega \mathrm{cm}$, Millipore; MQ), except for barnacle settlement assays, which used seawater, filtered and aged with aeration for at least a week. ${ }^{32}$ Pepsin (porcine, Pep), bovine serum albumin (BSA), and human fibrinogen (Fib) were obtained from Sigma; egg white lysozyme (Lys) from Fischer. Phosphate buffered saline (PBS) was prepared from tablets (Sigma), and adjusted to $\mathrm{pH} 7.4$ with $\mathrm{HCl}$ or $\mathrm{NaOH}$.

\section{SAM preparation}

Cleanroom-cleaned $0.5 \mathrm{~mm}$ thick Nexterion Glass B slides (Schott) were used in two dimensions; $40 \times 20 \mathrm{~mm}^{2}$ (for IRAS, ellipsometry and bacterial assays) or $15 \times 20 \mathrm{~mm}^{2}$ (for contact angle measurements and cyclic voltammetry). These were used as received for metal deposition in an electron-beam vacuum deposition system (base pressure $<3 \times 10^{-8} \mathrm{mbar}$ ). A $25 \AA \mathrm{Ti}$ (Balzers, 99.9\%) adhesion layer (deposited at a rate of $0.3-0.5 \AA / \mathrm{s}$ ) preceded a 2000 $\AA$ Au (Nordic High Vacuum AB, 99.99\%) layer (10 $\AA / \mathrm{s})$. For the SPR assays, 12 x $12 \mathrm{~mm}^{2}$ 
glass SPR chips coated with a $45 \mathrm{~nm}$ thick layer of gold were used (obtained from GE Healthcare, Uppsala, Sweden). Barnacle settlement assays were carried out in 24-well cell culture plates (Sarstedt, TC Plate 24Well F). These were gold-coated in a resistively-heated vacuum evaporation system with a base pressure of $<4 \times 10^{-6}$ mbar. A $30 \AA$ thick Ti adhesion layer was applied before a $300 \AA$ Au layer, at 0.5 and $10 \AA / s$, respectively. The well-plates were placed on a rotating sample holder, which was gradually inclined from $0^{\circ}$ to approx. $30^{\circ}$ from the horizontal during metal evaporation, to ensure coating of both the sides and the bottoms of the wells. ${ }^{33}$

All gold substrates, except the gold-coated well-plates for the cyprid assays, were washed in a 5:1:1 (by vol) mixture of MQ water, 30\% hydrogen peroxide and $25 \%$ ammonia, at $85{ }^{\circ} \mathrm{C}$ for 5 min (TL1-cleaning), rinsed under running MQ water, and then immediately placed in the thiol solutions. Due to the difficulties in TL1-washing the well-plates, these were instead filled with the thiol solutions immediately upon retrieval from the evaporation system. Peptides were dissolved in MQ water and the alkylthiols in ethanol, all to $50 \mu \mathrm{M}$ concentration. SAMs were prepared by incubation of gold substrates in the $50 \mu \mathrm{M}$ solutions for $24 \mathrm{~h}$. Before use, samples were sonicated for $2 \mathrm{~min}$ and then rinsed in water (peptides) or ethanol (alkylthiols), and dried in a stream of $\mathrm{N}_{2}$ before use.

\section{SAM characterization}

The wettabilities were assessed by advancing and receding water contact angle measurements in air, using a semi-automatic CAM 200 Contact Angle Meter (KSV Instruments Ltd., Finland) equipped with a manual liquid dispenser, and a video system with software for calculating contact angles. Three points were measured on each sample, and twenty data points (10 images) acquired on each point, during quasi-static expansion or retraction of the droplet. SAM thicknesses were determined with a Rudolph Research AutoEL III HeNe laser ellipsometer, with $\lambda=632.8 \mathrm{~nm}$ and a $70^{\circ}$ angle of incidence. The refractive indices of the TL1-cleaned gold substrates were determined before incubation. SAM thicknesses were calculated assuming a three-layer optical model (ambient/organic film/gold), with the refractive index of the SAM set to 1.5. Five spots were measured on each sample, and the average calculated for each sample. Data represents the averages of 3-5 samples prepared on different occasions. Fourier-transform infrared reflection-absorption spectroscopy (IRAS) was used to determine the chemical structure of the SAMs. A Bruker IFS66 system with a custom-built accessory for IRAS was used, with an incidence angle of $85^{\circ}$, and a liquid nitrogen-cooled mercury cadmium telluride detector. A deuterated hexadecanethiol (HS(CD $)_{15} \mathrm{CD}_{3}$, CDN Isotopes) SAM on gold was used to record the background spectrum. Cyclic voltammetry (CV) was conducted in a teflon cell, with the gold substrate supporting the SAM as the working electrode, pressed onto an opening with a rubber ring defining an exposed area of $0.26 \mathrm{~cm}^{2} .{ }^{34} \mathrm{An} \mathrm{Ag} / \mathrm{AgCl}$ (3 M NaCl, BAS) reference electrode and a platinum wire counter-electrode were also immersed in the cell. Measurements were carried out in $1 \mathrm{mM} \mathrm{K}_{3} \mathrm{Fe}(\mathrm{CN})_{6}$ as the redox species, using $100 \mathrm{mM} \mathrm{KNO}_{3}$ as a supporting electrolyte to increase the conductivity. The measurements were cotrolled via an Autolab PGSTAT20 electrochemical system (Eco Chemie). Voltammograms were obtained at a sweep rate of $30 \mathrm{mV} / \mathrm{s}$. 


\section{Barnacle assays}

Balanus (=Amphibalanus) amphitrite (Darwin) were synchronously mass cultured, fed Skeletonema costatum 28 C, in 35 PSU filtered aged sea water on a 14:10 light:dark cycle in 4 days from newly released nauplii, as per Rittschof et al. ${ }^{32}$ Day of metamorphosis to cyprid was Day 0. Settlement of cyprids incubated at $28^{\circ} \mathrm{C}$ on a $14: 10 \mathrm{~L}: \mathrm{D}$ cycle in a 24 hour interval depends upon cyprid age when stored at $6{ }^{\circ} \mathrm{C}$. Day 0 and Day 1 cyprids are best for studies of settlement induction, Day 3 cyprids are best for studies of settlement inhibition. A final assay which is conducted for multiple days determines how unacceptable the surface is because given the choice of settling or dieing, barnacle larvae settle. Cyprid settlement assays were conducted in 24 well plates with larvae of the appropriate age to answer the question being asked.We added $2 \mathrm{ml}$ of 1 micron filtered sea water aged for at least a week with aeration and then added 10 to 20 day 3 settlement stage barnacle larvae. ${ }^{32}$ Each plate was covered with the lid and incubated at $28^{\circ} \mathrm{C}$ for 24 hours for up to 3 days. Larvae and juvenile barnacles were killed with a drop of $10 \%$ formalin and scored as attached and not attached. Attached barnacles were those that had secreted permanent adhesive and had metamorphosed to juvenile or were in the process of metamorphosis.

\section{M. marinum assay}

M. marinum expressing mCherry were inoculated in 7H9 broth containing $0.05 \%$ Tween 80 and grown in standing culture for 3 days at $30{ }^{\circ} \mathrm{C}$. The culture was harvested by centrifugation (5000g, $5 \mathrm{~min}$ ), washed in PBS with $0.05 \%$ Tween80 and recentrifuged. The bacterial pellet was resuspended in Sauton's medium and seeded at $3 \times 10^{7}$ bacteria/well in quadriPERM dishes carrying the $40 \times 20 \mathrm{~mm}^{2}$ SAM-coated slides using the same medium. These were incubated at $30 \mathrm{C}^{\circ}$ for $24 \mathrm{~h}$ before washing the slides gently with PBS and fixing the samples with $4 \%$ paraformaldehyde for $30 \mathrm{~min}$ at room temperature. Fixed slides were mounted for microscopy using Dako Fluoresence Mounting Medium.

The density of adhered bacteria was determined using a Nikon Ti-E epifluorescence microscope with a 40x objective, IntensiLight illumination, and excitation/emission bandpass filters covering 550-570 nm and 580-630 nm, respectively. 64 fields of view (each covering $215 \times 160 \mu^{2}$ ) were collected from an $8 \times 8$ grid over $5 \times 5 \mathrm{~mm}^{2}$, at two different positions on each slide, and saved as monochromatic images. The cording morphology of M. marinum makes counting of the adhered bacteria difficult, and instead the total fluorescence intensity was integrated for every image, and the presented data for each assay are averages of intensities from 2 x 64 images. All image processing was conducted in MATLAB.

\section{Protein and Serum adsorption}

Proteins were dissolved in PBS to $1 \mathrm{mg} / \mathrm{ml}$ on the day they were used. Whole blood was donated from healthy volunteers at the blood bank at Linköping University Hospital. Serum was collected using Vacuette Z Serum Sep Clot Activator tubes (Greiner Bio-One) and centrifugation at $1800 \mathrm{~g}$ for $10 \mathrm{~min}$. The serum was diluted with PBS to $10 \%$ or $70 \%$. All solutions were degassed with a water jet pump before use. Adsorption tests from protein solutions and serum were conducted with a Biacore 3000 SPR system (GE Healthcare) at 25 ${ }^{\circ} \mathrm{C}$ and at a flow rate of $10 \mathrm{ml} / \mathrm{min}$, with PBS as the running buffer. After docking a SAMmodified chip, running buffer was flushed over the surface for 10 min for equilibration, followed by a 10 min protein or serum injection. After this injection, a 1 min flow of running 
buffer was used to remove loosely bound material, before reading the response. Data are presented as absolute differences in resonance units (RUs) after the 10 min equilibration, but before protein injection, and at $60 \mathrm{~s}$ after the end of the protein or serum injection.

\section{Statistical analysis}

For the different biofouling assays one-way analysis of variance (ANOVA) was used to compare the effects of the different surface coatings on the means, and where they were significantly different, a Tukey's HSD test was used to compare the coatings. For analysis of the barnacle cyprid settlement assay, Kruskal-Wallis analysis, followed by Dunn's tests were used. All statistical analyses were performed in MATLAB.

\section{Results and discussion}

\section{The design of the peptides}

The amino acid-sequences of the five tested peptides, as well as the alkylthiols used as controls, are shown in Table 1 (the labels for the peptides and alkylthiols in Table 1 will be used to refer to both the peptides/thiols, or the SAMs formed from them, with clarification only where there is possible ambiguity). All peptides have a Cys residue, whose free thiol group spontaneously reacts with gold to covalently attach the peptide to the gold substrates. Four of the peptides, 2-5, are based on repeating EK motifs. In a series of papers, Jiang et al. have investigated and optimized peptides with this motif, 23, 27-29, 35 and also made some observations suggesting why this combination might be more effective than many other zwitterionic residues; i) E and K commonly occur on protein surfaces, particularly in the crowded cytoplasm, ii) they are the most frequently occuring amino acids on the interior of molecular chaperones, and iii) $\mathrm{E}$ and $\mathrm{K}$ interacts stronger with water than with any other amino acids, and also lack sequence patterns. ${ }^{27}$ Our selection of peptides builds on this knowledge, but also involves other considerations.

Table 1. Amino acid-sequences of the peptides, the structures of the alkylthiols used as controls, and results of the physico-chemical characterization of all SAMs; including ellipsometric thickness $(d)$, average thickness per amino acid (d/aa).

\begin{tabular}{|c|l|c|c|c|}
\hline & Structure & $\begin{array}{c}\text { Net charge } \\
\text { at } p H 7.4\end{array}$ & $d(\AA)$ & $\begin{array}{c}d / a a \\
(\AA)\end{array}$ \\
\hline $\mathbf{1}$ & CPPPPSGKGSSGSST & 0.8 & $19.4 \pm 1.4$ & 1.29 \\
\hline $\mathbf{2}$ & CPPPPKEKEKEK & 0.8 & $18.5 \pm 0.5$ & 1.54 \\
\hline $\mathbf{3}$ & EKEKEKEPPPPC-Am & 0.2 & $21.0 \pm 0.6$ & 1.75 \\
\hline $\mathbf{4}$ & CALNNKEKEKEK & 0.8 & $16.9 \pm 0.8$ & 1.41 \\
\hline $\mathbf{5}$ & CFGAILSSKEKEKEK & & $22.4 \pm 1.4$ & 1.59 \\
\hline $\mathbf{m P E G}$ & HS- $\left(\mathrm{CH}_{2}\right)_{11}-\mathrm{CONH}-\left(\mathrm{C}_{2} \mathrm{H}_{4} \mathrm{O}\right)_{11}-\mathrm{CH}_{3}$ & 0 & $33.3 \pm 0.8$ & \\
\hline $\mathbf{E G} 6$ & HS- $\left(\mathrm{CH}_{2}\right)_{15}-\mathrm{CONH}-\left(\mathrm{C}_{2} \mathrm{H}_{4} \mathrm{O}\right)_{6}-\mathrm{OH}$ & 0 & $39.9 \pm 0.7$ & \\
\hline $\mathbf{C} \mathbf{1 6}$ & HS- $\left(\mathrm{CH}_{2}\right)_{16}-\mathrm{CH}_{3}$ & 0 & $21.6 \pm 0.3$ & \\
\hline
\end{tabular}


Peptide $\mathbf{1}$ is based on a structure introduced by Chelmowski, ${ }^{36}$ who in turn based the design on the guiding principles for protein resistant surfaces by Ostuni et al., suggesting that such surfaces should be hydrophilic, present hydrogen-bond acceptors (but not donors), and be overall charge-neutral. ${ }^{37}$ The $\mathrm{CP}_{4}$ anchor sequence was not part of the original design, but was added to the 'antifouling' SGKGSSGSST sequence to facilitate comparisons with peptides 2 and 3.

Peptide $\mathbf{2}$ is perhaps best explained as a 'reversed' version of peptide 3, but it is similar to an EK-featuring peptide by Kakegawa et al., ${ }^{38}$ with the difference that the original $\mathrm{CG}_{3}$ linker has been replaced by the $\mathrm{CP}_{4}$ linker.

Peptide 3 has been explored and exploited by Jiang et al. ${ }^{27-28}$ and represents an 'inverse' geometry, in that the Cys residue is located at the C-terminal, whereas it is placed at the $\mathrm{N}$ terminal on all other peptides.

The polyproline $\mathrm{CP}_{4}$ linker sequence has been demonstrated to improve peptide packing on the surface, and also antifouling properties, for peptide 3 , when compared to a similar peptide without this linker. ${ }^{28}$ Polyproline sequences form extended helices, and in the same study, IR data indicated helical structures also for the $\mathrm{CP}_{4}$ linker sequence of $\mathbf{3}$ when adsorbed to a gold surface, though the data was not conclusive with regard to the formed structure. ${ }^{28}$

To make a SAM that is as stable as possible, and which also effectively prevents penetration of foulants through the SAM to the gold, the monolayer should be dense and chains as closely packed as possible. This is easily obtained with $\omega$-functionalized alkylthiols of sufficient length, which pack effectively into a crystalline layer, but which is much more difficult to achieve with irregularly shaped polypeptides. This has been investigated by Lévy et al.; with a view to preparing coatings to stabilize gold nanoparticles, and starting from protein folding considerations, they arrived at a self-assembling pentapetide, CALNN, which forms particularly dense monolayers. ${ }^{39}$ Hypothesizing that this motif could increase the stability and packing density of a zwitterionic peptide layer, we attached an oligo-EK segment onto the CALNN sequence, resulting in peptide 4. Later, Lévy et al. developed this concept further, and a different capping agent, based on an amyloidogenic sequence of the polypeptide amyline, was developed; CFGAILSS. ${ }^{40}$ It was also found that CALNN and CFGAILSS form different structures (random coils and antiparallel $\beta$-sheets, respectively) ${ }^{40}$, and we considered it of interest also to use the latter motif for anchoring oligo-EK segments to gold substrates, which resulted in peptide 5 .

All peptides were designed to be near charge-neutral at neutral $\mathrm{pH}$ (and in our case also at the $\mathrm{pH}$ of seawater, about 8.2), though this is difficult to predict. Common tools for assessing the $\mathrm{pI}$ or the charge at a given $\mathrm{pH}$ (of which there are several available online) use data for free amino acids, which are not accurate for folded peptides, and even less so for peptides in a SAM, where charge regulation might be considerable.

The alkylthiols included in the study are used as negative (EG6 and $\mathbf{~ P P E G ) ~ a n d ~ p o s i t i v e ~}$ (C $\mathbf{1 6}_{\mathbf{6}}$ controls in the biofouling assays.

\section{Characterization of the monolayers}

The quality of the peptide (and alkylthiol) SAMs was investigated by ellipsometric thickness measurements, wettability tests, IRAS and cyclic voltammetry. The three alkylthiol SAMs 
which are used as control samples in the assays, form monolayers for which the characterization results agree with previously published data, and we refer to earlier work for details for each of these SAMs $\left(\mathbf{C}_{\mathbf{1 6}}{ }^{41}, \mathbf{E G}_{\mathbf{6}}{ }^{31}, \mathbf{m P E G}^{42}\right)$.

All peptide SAMs have advancing (and also receding) contact angles $<10^{\circ}$, as measured by the sessile drop method (further analysis by Wilhelmy balance did not reveal distinguishable differences), and we conclude that all peptide surfaces are strongly hydrophilic.

Ellipsometric thicknesses of the SAMs are reported in Table 1, as well as the averaged length per amino acid, calculated from the ellipsometric thicknesses. Peptides $\mathbf{1}$ and $\mathbf{5}$ have 15 amino acids, while the other three have 12; this difference is not obviously reproduced in the measured thicknesses, and the thicknesses are thus no immediate guide to the orientation or ordering of the peptides in the monolayers. The SAM 3 is 14\% thicker than its reversed version 2, a difference which is not explained by the amidation of the Cys residue in the former, but which thus reflects a difference in orientation on the surface. Nowinski et al. found that $\mathbf{3}$ has an extended, helical structure, promoted by the proline linker. ${ }^{28}$ and it is clear that this is different with the Cys residue placed on the $\mathrm{N}$ - or C-terminals. Table 1 also shows that $\mathbf{3}$ has the greatest length per amino acid of all peptides, with thickness per amino acid decreasing in the following order: $\mathbf{3}>\mathbf{5}>\mathbf{2}>\mathbf{4}>\mathbf{1}$. For similar amino acid content, a more stretched configuration correlates with a more densely packed layer, and a direct comparison seems fair for peptides 2-4, while $\mathbf{1}$ and $\mathbf{5}$ are too different in their compositions to permit a direct comparison.

IRAS analysis can provide information about both composition and orientation of molecules adsorbed onto metal surfaces, and was used for characterization of the peptide SAMs, and in particular to assess the stability of the SAMs to immersion in water (and also to shipment, see Figure S2 in Supporting Information). The IR spectra of peptides and proteins have characteristic amide bands from the backbone (amide I at $1600-1700 \mathrm{~cm}^{-1}$ from C $=\mathrm{O}$ stretching, amide II at about $1500-1600 \mathrm{~cm}^{-1}$ primarily from N-H bending with a C-N stretch contribution, and amide III near $1230 \mathrm{~cm}^{-1}$ from N-H bending and C-N stretching). The amide I and II regions for the five peptides are shown in Figure 1, and the presence of the amide bands is a clear indication of the formation of peptide monolayers on the surfaces (the corresponding peak positions are included in Table S1 in the Supporting Information), and from the variations in shapes and peak positions, it is clear that there are qualitative differences between the peptide's structures. The secondary structure of peptides can be inferred from analysis of the amide bands, which are sensitive to both secondary structure and environmental factors. A detailed analysis of these bands, and in particular their possible relation to secondary structure, is beyond the scope of this work, but this issue is further commented on in the Supporting Information. The stability of the peptide SAMs was assessed by comparing spectra before and after immersion in PBS for seven days, as shown in Figure 1 (results for immersion in artificial seawater is similar). Peptides $\mathbf{2}$ and $\mathbf{4}$ show a slight decrease in integrated intensity over the shown region after seven days, indicating loss of peptides, and a somewhat unstable monolayer. Peptide $\mathbf{1}$ appears to be very much unaffected by the process, which is attributed to the uncharged nature of the peptide; all other peptides are highly charged, and immersion in a solution of high salinity (like PBS or artificial seawater) is expected to affect any interactions between the charged residues of the peptides, and hence their interaction in a monolayer. Peptides $\mathbf{3}$ and $\mathbf{5}$ show a redistribution of the intensities from the amide I to the amide II bands. This is related to reorientation of the 
peptides on the surfaces. According to the surface selection rule for IRAS, only vibrational modes with associated dipole moment changes perpendicular to the surface are visible, and a decrease in amide I vibration is consistent with an orientation of the carbonyl bonds that is more parallel to the substrate, and is in agreement with an increase in amide II intensity, though more than one vibrational mode contributes to the latter, which complicates the interpretation, but taken together, this could indicate a more upright position of the peptide. Overall, the changes are small for all but peptide 2, indicating that the peptide SAMs are stable in water for a period exceeding the duration of the fouling assays.

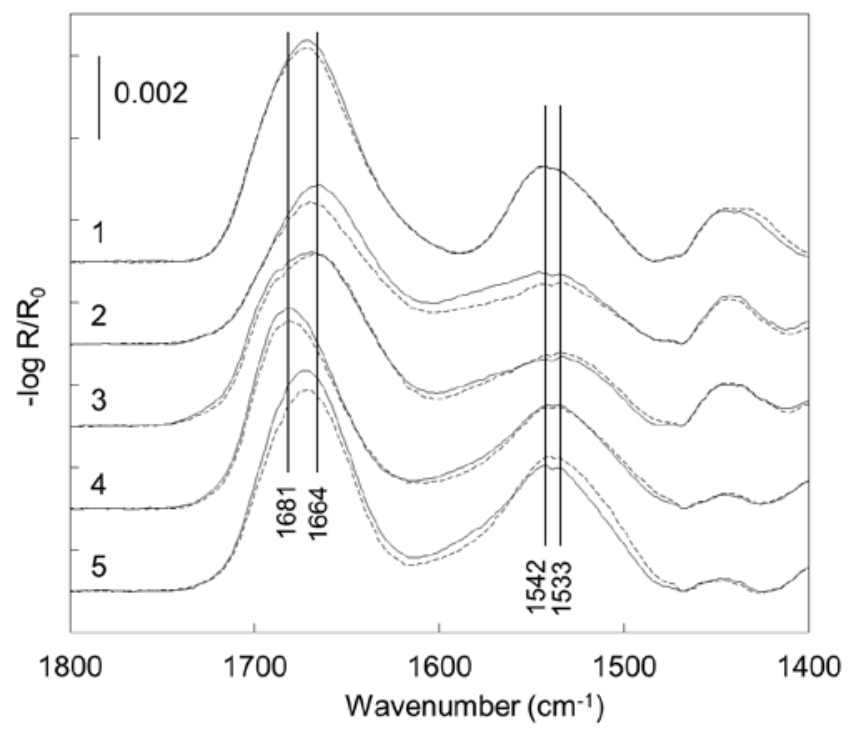

Figure 1. IRAS data in the amide I and II bands for the five peptides (1-5), before (solid lines) and after (dashed lines) immersion in PBS for 7 days. Vertical lines indicate boundaries for the amide I and II peak positions, respectively.

Cyclic voltammetry was used to provide additional information about the density of the peptides SAMs, and the result is shown in Figure 2. The results for a bare gold surface and for the $\mathbf{C}_{16}$ SAM are included for comparison. On the bare gold surface, the electrode reaction is bulk diffusion-limited, and a decrease in current relative to the bare gold appears for the SAMs a result of the SAMs blocking electron transport. Long-chain alkylthiol SAMs form dense and crystalline monolayers which effectively hinder electron transport, and the currents through the peptide SAMs are much greater (the peak current for $\mathbf{C}_{16}$ is $0.06 \mu \mathrm{A}$ in the shown potential range), indicating that the peptides form much less dense, and presumably less ordered monolayers. Overall, it emerges from the voltammograms that the peptide SAMs hinder the current, the double 'peak' of $\mathbf{1}$ (which is also weakly present for $\mathbf{2}$ and $\mathbf{4}$ ) suggests that some process, perhaps a reorganization of the layer, hinders the current as the potential increases, though this could also be an electrostatically hindered diffusion of the redox species to the surface, due to charging of the interface. The overall magnitude of the currents indicate that the peptides themselves are not involved in redox reactions. To the extent that the observed currents can be used as a measure of the packing density of the SAMs, this increases with decreasing current. Hence, $\mathbf{2}$ and $\mathbf{4}$ appear to have a relatively open structure, and the density of the SAMs increases as $\mathbf{2 , 4}<\mathbf{1}<\mathbf{3}<\mathbf{5}$. This is in qualitative agreement with some 
of the observations made in the previous. Lévy optimised the CFGAILSS linker sequence in $\mathbf{5}$ for packing density) ${ }^{40}$, and Jiang found that the proline linker of $\mathbf{3}$ forms relatively dense layers ${ }^{28}$; these two clearly form the best insulating SAMs, and are quantitatively distinctly different from $\mathbf{1}, \mathbf{2}$, and $\mathbf{4}$, between which there are slight differences, though the data does not allow further conclusions to be drawn from these.

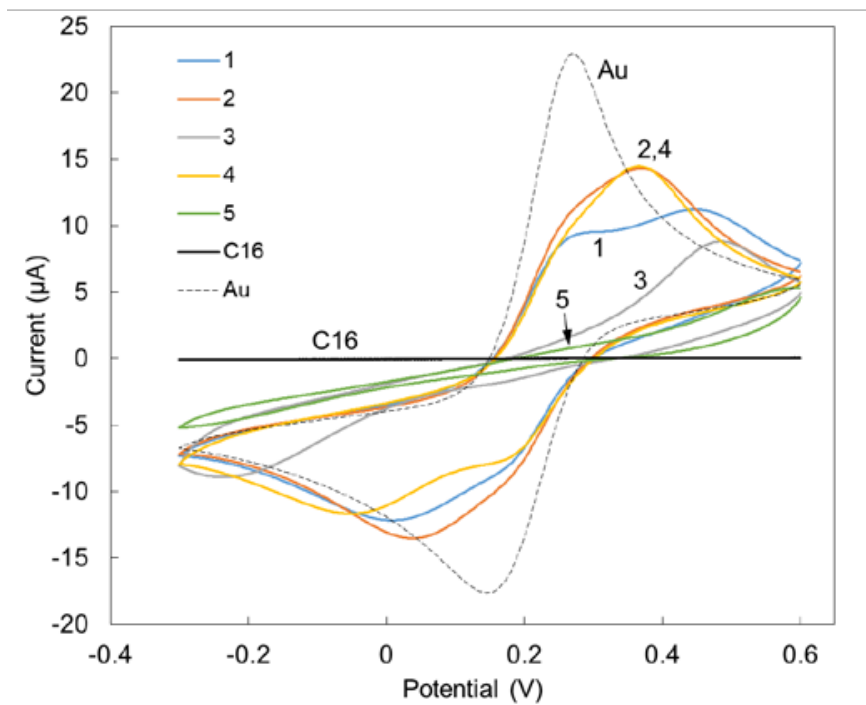

Figure 2. Cyclic voltammogram of the peptide SAMs 1-5, including also a bare gold surface (Au) and the $\mathbf{C}_{16}$ alkylthiol SAM. On the shown scale, the current for the $\mathbf{C}_{\mathbf{1 6}}$ sample hardly raises over the horizontal axis.

We conclude from the characterization of the SAMs that stable, well-organized, and very hydrophilic monolayers are formed from all five tested peptides. There are variations in the structure of the peptides; this is confirmed by the IRAS measurements, and is reflected in variations in the cyclic voltammograms, which are sensitive to the densities of the layers. Peptides $\mathbf{3}$ and $\mathbf{5}$ form denser, and most likely more stable layers than the other peptides, though a detailed structural characterization of the SAMs has not been conducted.

\section{Biofouling tests}

In many fouling environments, there is a hierarchy of foulants, operating on different lengthand timescales, and which may or may not be dependent on each other. For example, in biofluids, adsorbed proteins assist in the attachment of cells or bacteria and subsequent biofilm growth. Similarly, in marine environments, macromolecular adsorption precedes, and is sometimes a prerequisite or a determinant for subsequent macrofouling. The use of different types of model fouling species is thus justified by the widely varying types of fouling that will challenge an immersed surface in a biofluid, or in natural waters.

\section{Protein adsorption from solution}

Resistance to non-specific protein adsorption was tested with four different proteins; BSA, fibrinogen, lysozyme and pepsin, each at $1 \mathrm{mg} / \mathrm{ml}$ solutions in PBS. The proteins were 
selected to cover different sizes, from 14 to $340 \mathrm{kDa}$ (Lys and Fib, respectively); globular and non-globular conformations (BSA and Fib, respectively), and differences in net charge, with pI ranging from 2.2 (Pep) to 11 (Lys). The resulting adsorptions presented in Figure 3 show that there are significant differences between the surface types for all proteins (ANOVA, $\mathrm{p}<$ 0.001 in all cases), but pairwise comparison shows that the adsorption for any given peptide does not differ from that of any other peptide (or $\mathbf{E G}_{\mathbf{6}}$ ), for any of the proteins. Thus, the peptides, and also EG6, performs equally well in this assay. The considerably higher adsorption of fibrinogen, relative to the other three proteins, is in agreement with a large body of literature on protein adsorption, testifying to the promiscuous adsorption of Fib to a wide variety of surface types. This is a result of its structure, including both hydrophobic and hydrophilic regions, as well as domains with both net positive or negative charge, facilitating adsorption onto widely different surfaces. ${ }^{43}$

The resonance shift, expressed in RU, can be converted to adsorbed mass via $\Delta m=C_{\mathrm{SPR}} \Delta \mathrm{RU}$, where $C_{\mathrm{SPR}}$ is $6.5 \times 10^{-2} \mathrm{ng} / \mathrm{cm}^{2}$ for adsorption onto planar surfaces. ${ }^{44}$ Recalculation of the data in Figure 3 yields a maximum of $27 \mathrm{ng} / \mathrm{cm}^{2}$ of adsorbed fibrinogen on any of the peptide SAMs, and slightly less for the other proteins. The greatest variation is found for Pep, with adsorption in the range $2.3-18.1 \mathrm{ng} / \mathrm{cm}^{2}$ for all peptide SAMs (Table S2 in Supporting Information shows the calculated adsorbed masses for all samples). However, the relatively large standard deviations for the data in Figure 3 (reflected also in the insignificant differences upon pairwise comparisons in the data set) precludes further discrimination between the fouling resistance of the SAMs. Thus, we conclude that the peptide SAMs perform equally well in this assay, and on a par with EG6.

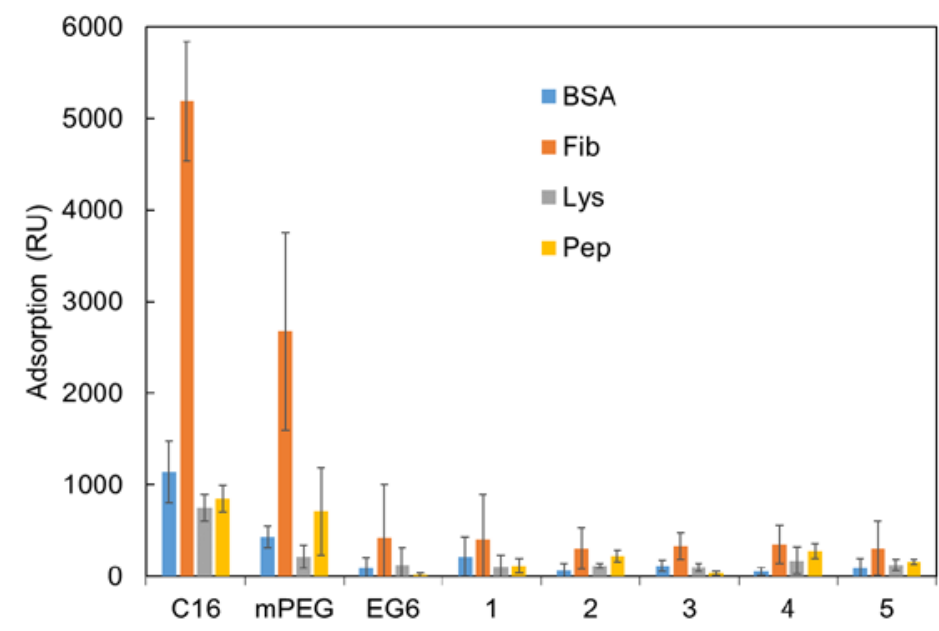

Figure 3. Adsorption of four different proteins from PBS solutions $(1 \mathrm{mg} / \mathrm{ml})$, as obtained using surface plasmon resonance, for the control and peptide SAMs. Error bars are \pm standard deviations $(N=3)$. 


\section{Blood serum}

We chose to use blood serum as a model for a complex biofluid, with variable composition, and which often induces non-specific adsorption onto materials which resist adsorption from individual protein solutions. The data is the result of two assays which were performed with samples from different patients, but the data is nevertheless very consistent. In this assay, the results for peptides $\mathbf{4}$ and $\mathbf{5}$ are different from those of the other peptides (and for $70 \%$ serum also between the two assays). The results for peptides 1-3 are indistinguishable from the results for both $\mathbf{m P E G}$ and $\mathbf{E G}_{\mathbf{6}}$, for both serum concentrations. Recalculation of the adsorption from resonance units to masses, yields $<77 \mathrm{ng} / \mathrm{cm}^{2}$ adsorption onto peptides 1-3, but $<331 \mathrm{ng} / \mathrm{cm}^{2}$ adsorption onto peptides $\mathbf{4}$ or $\mathbf{5}$ (Figure S3 in Supporting Information shows the data in Figure 4 recalculated into adsorbed mass).

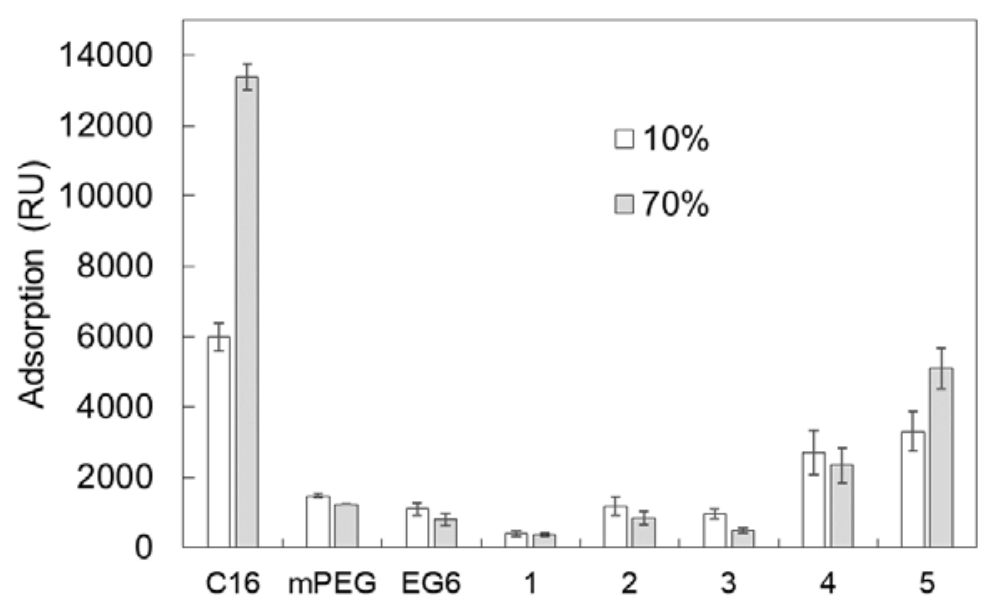

Figure 4. Result of the blood serum assays, performed with serum diluted to $10 \%$ or $70 \%$ with PBS. The adsorption was measured using surface plasmon resonance. Error bars are \pm standard deviations $(N=2)$.

\section{Bacterial attachment assays}

M. marinum is a biofilm-forming bacterium which is ubiquitous in freshwater, marine and brackish waters, and which is also associated with domestic water supplies. ${ }^{45} \mathrm{M}$. marinum is a source of mycobacteriosis in fish, and is of great concern to aquaculture, it can spread to mammals, and also affect humans. The strain that was used for the assay has a cording morphology ${ }^{46}$ which is evident in the micrographs, showing images from the series obtained on the control chemistries $\mathbf{C}_{\mathbf{1 6}}$ and $\mathbf{E G}_{6}$ and also peptide $\mathbf{1}$ (Figure 5). Quantitative data for bacterial attachment is shown in Figure 6. The attachment data differed significantly with surface chemistry ( $p<0.001$ at 95\% confidence, ANOVA), and pairwise comparisons show

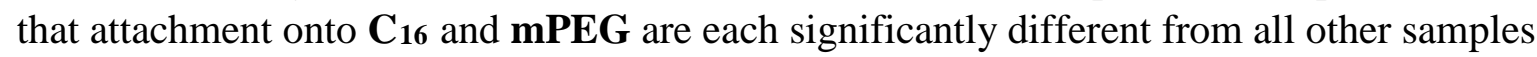

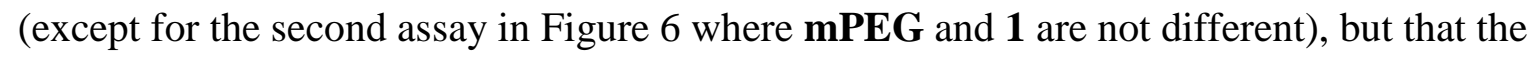
$\mathbf{E G}_{6}$ and the peptide samples cannot be distinguished from each other (Tukey's test). During the assays, it was observed that 'rafts' of bacterial biofilm floated off the surface of $\mathbf{m P E G}$ samples after the attachment step, similar to what has been observed for algal spore colonies on ethylene glycol-terminated SAMs. ${ }^{47}$ This indicates that a biofilm was formed, but that the 
adhesion to the surface was very weak. Many of the images from the $\mathbf{E G}_{\mathbf{6}}$ and the peptide samples did not have any attached bacteria in the field of view, and in the data for these samples, there is a bias toward higher attachment. This is caused by the necessity to ensure that the images were acquired with the sample surface in focus, and for the collection of fluorescence images in reflection through the opaque substrate, this is best done by finding a region with at least some attached bacteria, for focusing. Literature on $M$. marinum attachment or biofilm formation is scant, but our results are in agreement with previous observations that bacterial attachment correlates positively with surface hydrophobicity. ${ }^{46}$ The positive relationship is thought to relate to the ease of displacing water by bacterial extracellular polysaccharides which are relatively weak adhesives.

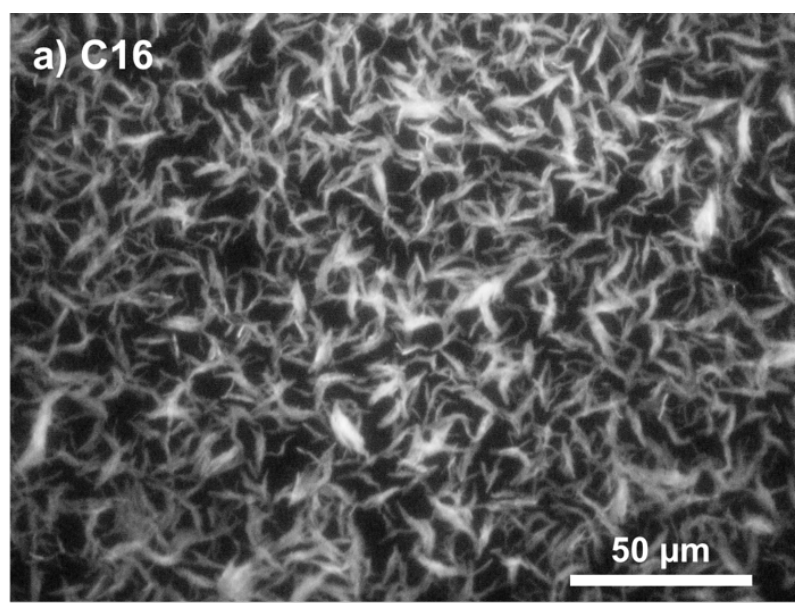

\section{b) MPEG}

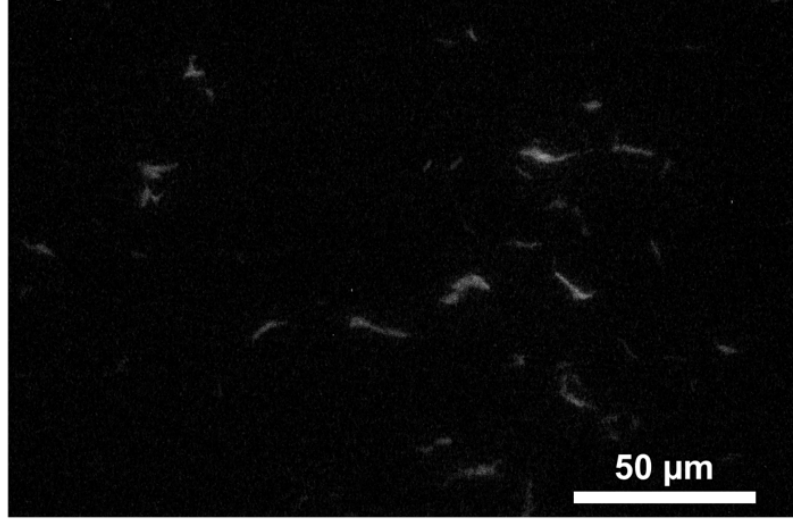

\section{c) Peptide 1}


Figure 5. Fluorescence images of $M$. marinum bacteria attached to (a) $\mathbf{C}_{\mathbf{1 6}}$, (b) $\mathbf{m P E G}$, and (c) the peptide $1 \mathrm{SAM}$. A vast majority of the images of the peptides 1-5 did not have any bacteria in the field of view.

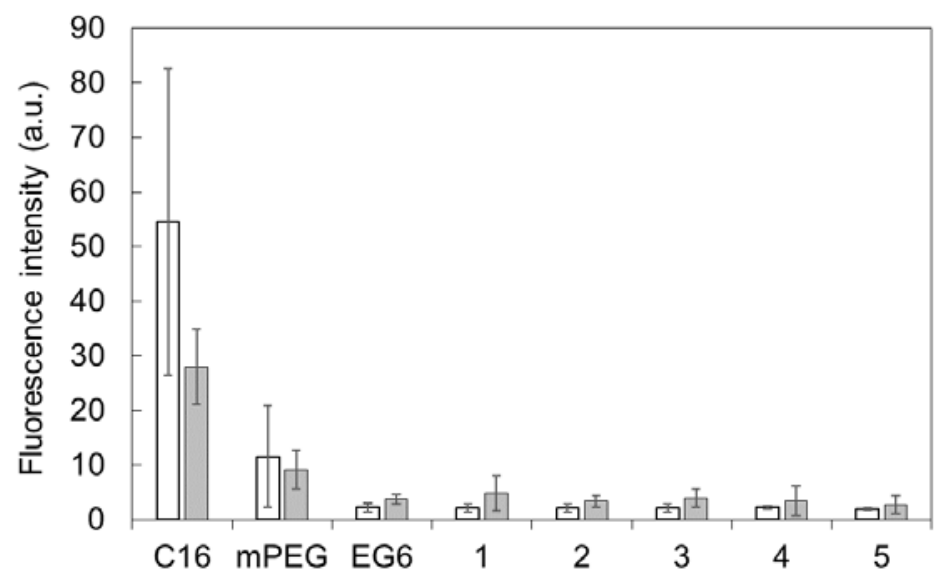

Figure 6. Attachment of bacteria onto the control surfaces and the peptide SAMs, from two independent experiments (white and gray bars, respectively). The error bars represent \pm standard deviations $(N=64)$.

\section{Barnacle settlement assays}

The barnacle Balanus amphitrite is an important marine fouling organism and the most studied macrofouling animal model. Barnacles effectively and gregariously colonize ship hulls and other immersed surfaces. Gregarious settlement is a result of a variety of pheromones, many of which are proteins like the settlement-inducing protein complex (SIPC). Other pheromones are water soluble ${ }^{48-49}$ and can be mimicked by short sequences of neutral, neutral basic tripeptides ending in $\mathrm{K}$ or $\mathrm{R} .{ }^{50}$ An example of this kind of tripeptide is GlycineGlycine-Arginine (GGR) which is a peptide pheromone mimic in crustaceans and molluscs. ${ }^{50}$ Unlike many other fouling organisms B. amphitrite larvae settle preferentially on hydrophilic surfaces, including glass cleaned by baking at $500^{\circ} \mathrm{C}$ and potentially hydrophilic surfaces generated by SAMs with attached peptides. A major interest in the field is discriminating between surface energy and pheromone effects.

The settlement assays using settlement stage larvae of $B$. amphitrite show significant variations between surface coatings (Kruskal-Wallis, $p<0.002$ ), and a Dunn's test comparing the peptides show that that settlement preferences are similar for all peptides, in both assays, except for peptide $\mathbf{3}$, for which settlement is nearly zero, and instead similar to that of the mPEG surface. (Note: in this assay, only mPEG was used as a negative control, based on previous knowledge about its suitability for this purpose, ${ }^{51}$ and which is also demonstrated by our results.) To ensure that the absence of settlement onto peptide 3 is not caused by toxicity, extended settlement tests were performed to ensure that cyprids were able to at all settle on these SAMs (Figure S4, Supporting Information).

The settlement results stand in sharp contrast to the settlement tests performed by Aldred et al., finding that cyprids of the same species did not settle on the zwitterionic polymers 
poly(sulfobetaine methacrylate) or poly(carboxybetaine methacrylate). ${ }^{52}$ As Aldred et al. used barnacles originating from the Rittschof facility, and raised them by similar techniques, we used larvae in very similar condition and are confident that both sets of results are correct. Quintana et al. investigated the settlement of cyprids of Amphibalanus amphitrite onto zwitterionic poly(sulfobetaine methacrylamide), poly(sulfobetaine vinylbenzene) and poly(sulfobetaine vinylimidazolium) brushes, with settlement approximately $10 \%$ for all three polymers. ${ }^{53}$ From this we must conclude that the peptide SAMs showing very high settlement in our barnacle larvae assay, have some, yet unidentified, property that is fundamentally different from the zwitterionic polymers tested above.

One possibility is that all of the SAM peptides that induced barnacle settlement contain a sequence of prolines associated with a lysine, the necessary sequence for settlement-inducing peptides, and it is conceivable that the SAMs presented this sequence through folding. Three of the four peptides with high settlement could potentially present a sequence that would promote settlement (peptide 1, PPPPSGK; peptide 2, PPPPK; peptide 5, ILSSK). Peptide 4 does not have the correct motif. A second possibility is exogenous serine proteases common in marine environments, clipped at the lysine carboxy terminal exposing the sequence. Water soluble peptide barnacle pheromone mimics stimulate settlement at nanomolar to picomolar levels. ${ }^{50}$ Again, this is an option for peptides 1, 2, and 5. A final possibility is that the results are due to the state of hydration. There is a fine line between having a hydrophilic surface and one that is so hydrated that it resembles water more than it does a surface. It is likely that all three mechanisms are operating.

The fact that the sample with the 'reversed' peptide $\mathbf{3}$ has very little settlement suggests that this peptide SAM is qualitatively different from the other SAMs, but the possible effects of a 'reversed' orientation on how the SAM is presented to cyprids is not immediately apparent. Peptide 3 differs from the other peptides with repeating EK motifs in that it is terminated with the anionic glutamic acid, whereas peptides $\mathbf{2 ,} \mathbf{4}$ and $\mathbf{5}$ expose a cationic lysine residue at the surface. Based on the results of a previous study, ${ }^{54}$ showing a preference of $B$. amphitrite cyprids for negatively charged SAMs, this cannot in itself explain the lower settlement on peptide $\mathbf{3}$. Peptide $\mathbf{3}$ is not only reversed, it does not contain the neutral, neutral basic motif, and cannot be degraded by trypsin-like serine proteases. At this point there is no complete answer to why these surfaces promote and deter settlement by the very complex and specialized crustacean larvae, which is currently the best studied, but still incompletely understood.

Recent work show that both chain spacing and flexibility are important for fouling resistance, ${ }^{55}$ and in comparison with polymers, SAMs typically lack in flexibility, and sometimes also in hydration capacity (with comparisons of chain spacing between SAMs and polymers remaining ambiguous). The CV results indicate that peptide $\mathbf{3}$, together with peptide $\mathbf{5}$, forms more dense layers than the other peptides, but this in itself does not seem to explain the absence of settlement onto $\mathbf{3}$, since settlement is high on peptide 5 . Presumably the 
reversed geometry of peptide $\mathbf{3}$ is important, but with only one peptide in this geometry, our data provides only weak support for such a claim.

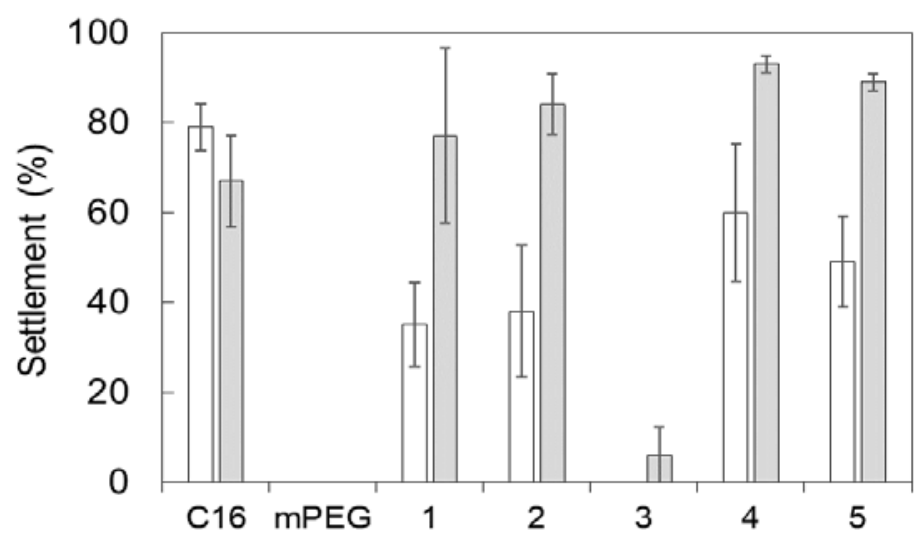

Figure 7. Mean percentage settlement of $B$. amphitrite cyprids after $24 \mathrm{~h}$, from two independent experiments. Error bars represent \pm standard deviations $(N=4)$.

\section{Comparison of the biofouling assays}

Zwitterions featuring repeating EK-motifs have demonstrated good resistance in previous studies. $^{23,27-29}$ in many cases showing antifouling properties similar to, or better than, the 'gold standard' PEG. However, as with many potentially antifouling chemistries, the results vary between assays, and a universal solution to fouling prevention remains to be seen. Our results partially confirm previous observations that zwitterionic materials have good antifouling properties, and that fouling resistance achieves the levels obtained by OEGterminated coatings. However, the results for blood serum and barnacle larvae are not in agreement with this, in that there are significant variations between the performance of the tested SAMs, and these variations are not coherent between the serum and cyprid assays.

The intention to compare the different peptide SAMs was successful insofar as we have identified a peptide (3) which does not induce settlement of barnacle cyprids, which was a specific aim of this study. We also note that this peptide performed well also in the other assays, and thus holds promise for a more general antifouling behaviour. The obtained results for the peptides are not sufficient to assess the effects of the structural changes between them, since for most of the assays, the results are not different enough to permit a discrimination of the effects of the materials on the performance. In particular, the fouling results for the two most densely packed peptide SAMs, 3 and 5, are significantly different in both the blood serum and barnacle larvae assays, and layer density as such is thus not a unique determinant of performance. Further, it is striking that peptides $\mathbf{1}$ and $\mathbf{2}$, where the former is chargeneutral, and the latter zwitterionic, perform similarly, and on a par with the fouling-resistant EG6 control, indicating that zwitterionic surfaces do not always confer improvement in antifouling. Instead of providing a solid basis for general conclusions with wider implications, our assays raise intriguing questions and stimulate speculation and attempts to 
interpret the remaining, small, differences in responses in terms of the structural differences between the peptides.

We believe that the manifest differences between the result for $\mathbf{3}$ and the other peptides in the cyprid settlement assay are worthy of further investigation, and that this could potentially provide valuable information about cyprid settlement mechanisms. We propose that order and packing density should be primary targets for such a study. This should be accompanied by a structural analysis of the peptide SAMs, but should also include additional 'reversed' peptides (i.e., with the Cys residue at the $\mathrm{C}$-terminal, rather than at the $\mathrm{N}$-terminal), and preferably also a direct determination of surface charge, for example via colloidal-probe AFM, to determine the actual surface charge density, and perhaps also its $\mathrm{pH}$-dependence.

\section{Summary and conclusions}

With a view of taking advantage of recent progress in antifouling methods based on zwitterionic materials, as well as progress in the design of peptides forming stable and dense self-assembled monolayers, we have tested peptides with structural variations in different fouling assays.

Our motivation for this work has been to provide a peptide SAM which is suitable for presentation of crustacean pheromones; this implies that the SAM itself should not induce settlement of larvae of the species of interest, and also that it should resist non-specific adsorption of macromolecules and bacteria, which could potentially interfere with the action of the studied pheromones. Hence, a series of assays using model biofouling species was used. The peptides were designed based on various sequences from literature sources, optimized for fouling resistance and/or stability and packing density. Characterization of the chosen peptides show that all form stable and more or less well-organized monolayers. IRAS and CV demonstrate clear differences between them, but structural details of these were not studied extensively. Wetting measurement show that all peptide SAMs are strongly hydrophilic.

Assays using protein solutions and the bacterium $M$. marinum showed no differences in the performance between the peptides, and also that all peptides have excellent antifouling properties, on a par with the well-known antifouling EG 6 SAM. For the assay quantifying adsorption from human serum, as well as the barnacle settlement assay, there were significant differences in the performance of the peptide SAMs; in the former, three of the peptides resisted fouling to a degree comparable to $\mathbf{E G}_{6}$ SAMs, while in the latter only peptide $\mathbf{3}$ prevented settlement of barnacle cyprids. The obtained data is insufficient to draw general conclusions about possible effects of the differences between the peptides and the results of the fouling assays, but it is clear from the results that the antifouling properties of peptides including the EK motif is partially confirmed by our data, but also that this is not the case for barnacle larvae settlement assays. 


\section{Acknowledgements}

We thank Caroline Brommesson for providing the blood serum, Karin Enander for assistance with the Biacore system, and Fredrik Björefors for advice on cyclic voltammetry. This work was carried out with financial support from the Swedish Research Council (Vetenskapsrådet, 2014-4004).

\section{Supporting Information}

Discussion about the IRAS data.

Transport stability test of peptide SAMs.

Additional data from the protein and serum assays.

Toxicity test for peptide $\mathbf{3}$ in the barnacle settlement assays. 


\section{References}

1. Krishnamoorthy, M.; Hakobyan, S.; Ramstedt, M.; Gautrot, J. E., Surface-Initiated Polymer Brushes in the Biomedical Field: Applications in Membrane Science, Biosensing, Cell Culture, Regenerative Medicine and Antibacterial Coatings. Chemical Reviews 2014, 114 (21), 10976-11026.

2. Yang, W. J.; Neoh, K.-G.; Kang, E.-T.; Teo, S. L.-M.; Rittschof, D., Polymer brush coatings for combating marine biofouling. Progress in Polymer Science 2014, 39 (5), 1017-1042.

3. Lowe, S.; O'Brien-Simpson, N. M.; Connal, L. A., Antibiofouling polymer interfaces: poly(ethylene glycol) and other promising candidates. Polymer Chemistry 2015, 6 (2), 198-212.

4. Morra, M., Poly(ethylene oxide) coated surfaces. In Water in biomaterials surface science, Morra, M., Ed. John Wiley: Chichester, 2001.

5. Prime, K. L.; Whitesides, G. M., Self-Assembled Organic Monolayers: Model Systems for Studying Adsorption of Proteins at Surfaces. Science 1991, 252 (5009), 1164-1167.

6. Herrwerth, S.; Eck, W.; Reinhardt, S.; Grunze, M., Factors that Determine the Protein Resistance of Oligoether Self-Assembled Monolayers - Internal Hydrophilicity, Terminal Hydrophilicity, and Lateral Packing Density. J. Am. Chem. Soc. 2003, 125 (31), 93599366.

7. Ladd, J.; Zhang, Z.; Chen, S.; Hower, J. C.; Jiang, S., Zwitterionic Polymers Exhibiting High Resistance to Nonspecific Protein Adsorption from Human Serum and Plasma. Biomacromolecules 2008, 9 (5), 1357-1361.

8. Jiang, S.; Cao, Z., Ultralow-Fouling, Functionalizable, and Hydrolyzable Zwitterionic Materials and Their Derivatives for Biological Applications. Advanced Materials 2010, 22 (9), 920-932.

9. Schlenoff, J. B., Zwitteration: Coating Surfaces with Zwitterionic Functionality to Reduce Nonspecific Adsorption. Langmuir 2014, 30 (32), 9625-9636.

10. Holmlin, R. E.; Chen, X. X.; Chapman, R. G.; Takayama, S.; Whitesides, G. M., Zwitterionic SAMs that resist nonspecific adsorption of protein from aqueous buffer. Langmuir 2001, 17 (9), 2841-2850.

11. Chen, S.; Zheng, J.; Li, L.; Jiang, S., Strong Resistance of Phosphorylcholine SelfAssembled Monolayers to Protein Adsorption: Insights into Nonfouling Properties of Zwitterionic Materials. Journal of the American Chemical Society 2005, 127 (41), 1447314478.

12. Chen, S. F.; Yu, F. C.; Yu, Q. M.; He, Y.; Jiang, S. Y., Strong resistance of a thin crystalline layer of balanced charged groups to protein adsorption. Langmuir 2006, 22 (19), 8186-8191.

13. Bauer, S.; Alles, M.; Finlay, J. A.; Callow, J. A.; Callow, M. E.; Rosenhahn, A., Influence of zwitterionic SAMs on protein adsorption and the attachment of algal cells. Journal of Biomaterials Science, Polymer Edition 2014, 25 (14-15), 1530-1539.

14. Huang, C.-J.; Wang, L.-C.; Liu, C.-Y.; Chiang, A. S. T.; Chang, Y.-C., Natural zwitterionic organosulfurs as surface ligands for antifouling and responsive properties. Biointerphases 2014, 9 (2), 029010. 
15. Lin, P.; Ding, L.; Lin, C.-W.; Gu, F., Nonfouling Property of Zwitterionic Cysteine Surface. Langmuir 2014, 30 (22), 6497-6507.

16. Pepe-Mooney, B. J.; Fairman, R., Peptides as materials. Current Opinion in Structural Biology 2009, 19 (4), 483-494.

17. Aili, D.; Stevens, M. M., Bioresponsive peptide-inorganic hybrid nanomaterials. Chemical Society Reviews 2010, 39 (9), 3358-3370.

18. Ramakers, B. E. I.; van Hest, J. C. M.; Lowik, D. W. P. M., Molecular tools for the construction of peptide-based materials. Chemical Society Reviews 2014, 43 (8), 27432756.

19. Costa, D.; Pradier, C.-M.; Tielens, F.; Savio, L., Adsorption and self-assembly of bioorganic molecules at model surfaces: A route towards increased complexity. Surface Science Reports 2015, 70 (4), 449-553.

20. Khatayevich, D.; Gungormus, M.; Yazici, H.; So, C.; Cetinel, S.; Ma, H.; Jen, A.; Tamerler, C.; Sarikaya, M., Biofunctionalization of materials for implants using engineered peptides. Acta Biomaterialia 2010, 6 (12), 4634-4641.

21. Bolduc, O. R.; Pelletier, J. N.; Masson, J.-F., SPR Biosensing in Crude Serum Using Ultralow Fouling Binary Patterned Peptide SAM. Analytical Chemistry 2010, 82 (9), 3699-3706.

22. Ederth, T.; Pettitt, M. E.; Nygren, P.; Du, C. X.; Ekblad, T.; Zhou, Y.; Falk, M.; Callow, M. E.; Callow, J. A.; Liedberg, B., Interactions of Zoospores of Ulva linza with ArginineRich Oligopeptide Monolayers. Langmuir 2009, 25 (16), 9375-9383.

23. Chen, S.; Cao, Z.; Jiang, S., Ultra-low fouling peptide surfaces derived from natural amino acids. Biomaterials 2009, 30 (29), 5892-5896.

24. Yang, Q.; Wang, L.; Lin, W.; Ma, G.; Yuan, J.; Chen, S., Development of nonfouling polypeptides with uniform alternating charges by polycondensation of the covalently bonded dimer of glutamic acid and lysine. Journal of Materials Chemistry B 2014, 2 (5), 577-584.

25. Ye, H.; Wang, L.; Huang, R.; Su, R.; Liu, B.; Qi, W.; He, Z., Superior Antifouling Performance of a Zwitterionic Peptide Compared to an Amphiphilic, Non-Ionic Peptide. ACS Applied Materials \& Interfaces 2015, 7 (40), 22448-22457.

26. Liu, Q.; Li, W.; Wang, H.; Newby, B.-m. Z.; Cheng, F.; Liu, L., Amino Acid-Based Zwitterionic Polymer Surfaces Highly Resist Long-Term Bacterial Adhesion. Langmuir 2016, 32 (31), 7866-7874.

27. White, A. D.; Nowinski, A. K.; Huang, W.; Keefe, A. J.; Sun, F.; Jiang, S., Decoding nonspecific interactions from nature. Chemical Science 2012, 3 (12), 3488-3494.

28. Nowinski, A. K.; Sun, F.; White, A. D.; Keefe, A. J.; Jiang, S., Sequence, Structure, and Function of Peptide Self-Assembled Monolayers. Journal of the American Chemical Society 2012, 134 (13), 6000-6005.

29. Liu, E. J.; Sinclair, A.; Keefe, A. J.; Nannenga, B. L.; Coyle, B. L.; Baneyx, F.; Jiang, S., EKylation: Addition of an Alternating-Charge Peptide Stabilizes Proteins.

Biomacromolecules 2015, 16 (10), 3357-3361.

30. Gooding, J. J.; Parker, S. G.; Lu, Y.; Gaus, K., Molecularly Engineered Surfaces for Cell Biology: From Static to Dynamic Surfaces. Langmuir 2014, 30 (12), 3290-3302. 
31. Svedhem, S.; Hollander, C.-Å.; Shi, J.; Konradsson, P.; Liedberg, B.; Svensson, S. C. T., Synthesis of a Series of Oligo(ethylene glycol)-Terminated Alkanethiol Amides Designed to Address Structure and Stability of Biosensing Interfaces. The Journal of Organic Chemistry 2001, 66 (13), 4494-4503.

32. Rittschof, D.; Clare, A. S.; Gerhart, D. J.; Mary, S. A.; Bonaventura, J., Barnacle in vitro assays for biologically active substances: Toxicity and Settlement inhibition assays using mass cultured Balanus amphitrite amphitrite darwin. Biofouling 1992, 6 (2), 115-122.

33. Petrone, L.; Di Fino, A.; Aldred, N.; Sukkaew, P.; Ederth, T.; Clare, A. S.; Liedberg, B., Effects of surface charge and Gibbs surface energy on the settlement behaviour of barnacle cyprids (Balanus amphitrite). Biofouling 2011, 27 (9), 1043-1055.

34. Yang, Z.; Engquist, I.; Wirde, M.; Kauffmann, J.-M.; Gelius, U.; Liedberg, B., Preparation and Characterization of Mixed Monolayer Assemblies Composed of Thiol Analogues of Cholesterol and Fatty Acid. Langmuir 1997, 13 (12), 3210-3218.

35. Keefe, A. J.; Caldwell, K. B.; Nowinski, A. K.; White, A. D.; Thakkar, A.; Jiang, S., Screening nonspecific interactions of peptides without background interference. Biomaterials 2013, 34 (8), 1871-1877.

36. Chelmowski, R.; Köster, S. D.; Kerstan, A.; Prekelt, A.; Grunwald, C.; Winkler, T.; Metzler-Nolte, N.; Terfort, A.; Wöll, C., Peptide-Based SAMs that Resist the Adsorption of Proteins. Journal of the American Chemical Society 2008, 130 (45), 14952-14953.

37. Ostuni, E.; Chapman, R. G.; Holmlin, R. E.; Takayama, S.; Whitesides, G. M., A Survey of Structure-Property Relationships of Surfaces that Resist the Adsorption of Protein. Langmuir 2001, 17 (18), 5605-5620.

38. Kakegawa, T.; Mochizuki, N.; Sadr, N.; Suzuki, H.; Fukuda, J., Cell-Adhesive and CellRepulsive Zwitterionic Oligopeptides for Micropatterning and Rapid Electrochemical Detachment of Cells. Tissue Engineering Part A 2013, 19 (1-2), 290-298.

39. Lévy, R.; Thanh, N. T. K.; Doty, R. C.; Hussain, I.; Nichols, R. J.; Schiffrin, D. J.; Brust, M.; Fernig, D. G., Rational and Combinatorial Design of Peptide Capping Ligands for Gold Nanoparticles. Journal of the American Chemical Society 2004, 126 (32), 1007610084.

40. Shaw, C. P.; Middleton, D. A.; Volk, M.; Lévy, R., Amyloid-Derived Peptide Forms Self-Assembled Monolayers on Gold Nanoparticle with a Curvature-Dependent $\beta$-Sheet Structure. ACS Nano 2012, 6 (2), 1416-1426.

41. Engquist, I.; Lundstroem, I.; Liedberg, B., Temperature-programmed desorption and infrared studies of D2O ice on self-assembled alkanethiolate monolayers: influence of substrate wettability. The Journal of Physical Chemistry 1995, 99 (32), 12257-12267.

42. Nugraha, R.; Finlay, J. A.; Hill, S.; Fyrner, T.; Yandi, W.; Callow, M. E.; Callow, J. A.; Ederth, T., Antifouling properties of oligo(lactose)-based self-assembled monolayers. Biofouling 2015, 31 (1), 123-134.

43. Feng, L.; Andrade, J. D., Structure and Adsorption Properties of Fibrinogen. In Proteins at Interfaces II, American Chemical Society: 1995; Vol. 602, pp 66-79.

44. Liedberg, B.; Lundström, I.; Stenberg, E., Principles of biosensing with an extended coupling matrix and surface plasmon resonance. Sensors and Actuators B: Chemical 1993, 11 (1), 63-72. 
45. Falkinham, J. O.; Norton, C. D.; LeChevallier, M. W., Factors Influencing Numbers of Mycobacterium avium, Mycobacterium intracellulare, and Other Mycobacteria in Drinking Water Distribution Systems. Applied and Environmental Microbiology 2001, 67 (3), 1225-1231.

46. Hall-Stoodley, L.; Brun, O. S.; Polshyna, G.; Barker, L. P., Mycobacterium marinum biofilm formation reveals cording morphology. FEMS Microbiology Letters 2006, 257 (1), 43-49.

47. Schilp, S.; Kueller, A.; Rosenhahn, A.; Grunze, M.; Pettitt, M. E.; Callow, M. E.; Callow, J. A., Settlement and adhesion of algal cells to hexa (ethylene glycol)-containing selfassembled monolayers with systematically changed wetting properties. Biointerphases 2007, 2 (4), 143-150.

48. Rittschof, D.; Branscomb, E. S.; Costlow, J. D., Settlement and behavior in relation to flow and surface in larval barnacles, Balanus amphitrite Darwin. Journal of Experimental Marine Biology and Ecology 1984, 82 (2), 131-146.

49. Tegtmeyer, K.; Rittschof, D., Synthetic peptide analogs to barnacle settlement pheromone. Peptides 1988, 9 (6), 1403-1406.

50. Rittschof, D.; Cohen, J. H., Crustacean peptide and peptide-like pheromones and kairomones. Peptides 2004, 25 (9), 1503-1516.

51. Maleshlijski, S.; Sendra, G. H.; Aldred, N.; Clare, A. S.; Liedberg, B.; Grunze, M.; Ederth, T.; Rosenhahn, A., Imaging SPR combined with stereoscopic 3D tracking to study barnacle cyprid-surface interactions. Surface Science 2016, 643, 172-177.

52. Aldred, N.; Li, G.; Gao, Y.; Clare, A. S.; Jiang, S., Modulation of barnacle (Balanus amphitrite Darwin) cyprid settlement behavior by sulfobetaine and carboxybetaine methacrylate polymer coatings. Biofouling 2010, 26 (6), 673-683.

53. Quintana, R.; Jańczewski, D.; Vasantha, V. A.; Jana, S.; Lee, S. S. C.; Parra-Velandia, F. J.; Guo, S.; Parthiban, A.; Teo, S. L.-M.; Vancso, G. J., Sulfobetaine-based polymer brushes in marine environment: Is there an effect of the polymerizable group on the antifouling performance? Colloids and Surfaces B: Biointerfaces 2014, 120, 118-124.

54. Di Fino, A.; Petrone, L.; Aldred, N.; Ederth, T.; Liedberg, B.; Clare, A. S., Correlation between surface chemistry and settlement behaviour in barnacle cyprids (Balanus improvisus). Biofouling 2014, 30 (2), 143-152.

55. Beckner, W.; He, Y.; Pfaendtner, J., Chain Flexibility in Self-Assembled Monolayers Affects Protein Adsorption and Surface Hydration: A Molecular Dynamics Study. The Journal of Physical Chemistry B 2016, 120 (40), 10423-10432. 


\title{
Supporting Information
}

for

\section{Resistance of zwitterionic peptide monolayers to biofouling}

\author{
Thomas Ederth $^{1, *}$, Maria Lerm², Beatriz Orihuela ${ }^{3}$, Daniel Rittschof ${ }^{3}$ \\ ${ }^{1}$ Division of Molecular Physics, Department of Physics, Chemistry and Biology, Linköping \\ University, SE-581 83 Linköping, Sweden \\ ${ }^{2}$ Division of Microbiology and Molecular Medicine, Department of Clinical and \\ Experimental Medicine, Linköping University, SE-581 83 Linköping, Sweden \\ ${ }^{3}$ Duke University Marine Laboratory, Nicholas School of the Environment, Duke University, \\ Beaufort, North Carolina 28516-9721, USA \\ * Corresponding author: thomas.ederth@liu.se
}

DOI: 10.1021/acs.langmuir.8b01625 


\section{IRAS analysis of the peptides}

Both the amide I and amide II bands are broad for all peptides, indicating some disorder or variability, or both, in the structure. Peptide 3 is notable in that its amide I band is obviously bimodal, which is true also for $\mathbf{1}$, but to a lesser extent (see Figure 1 in the main text). In practice, however, four peaks are required to fit the amide I band of $\mathbf{3}$ with any accuracy (see Figure S1), and none of the amide I bands for any of the peptides 1-5 can be fitted with less than three separate peaks (not shown). Assigning the structural source for each of these, or identifying the associated secondary structure, is far from trivial, and the problems and pitfalls associated with a direct interpretation of absolute amide band peak positions into secondary structure are several, and well documented. ${ }^{1-3}$ A proper analysis of this rather complex situation is beyond the scope of this work, and we thus refrain from this. However, amide I and amide II peak positions for the five peptides are included in Table S1.

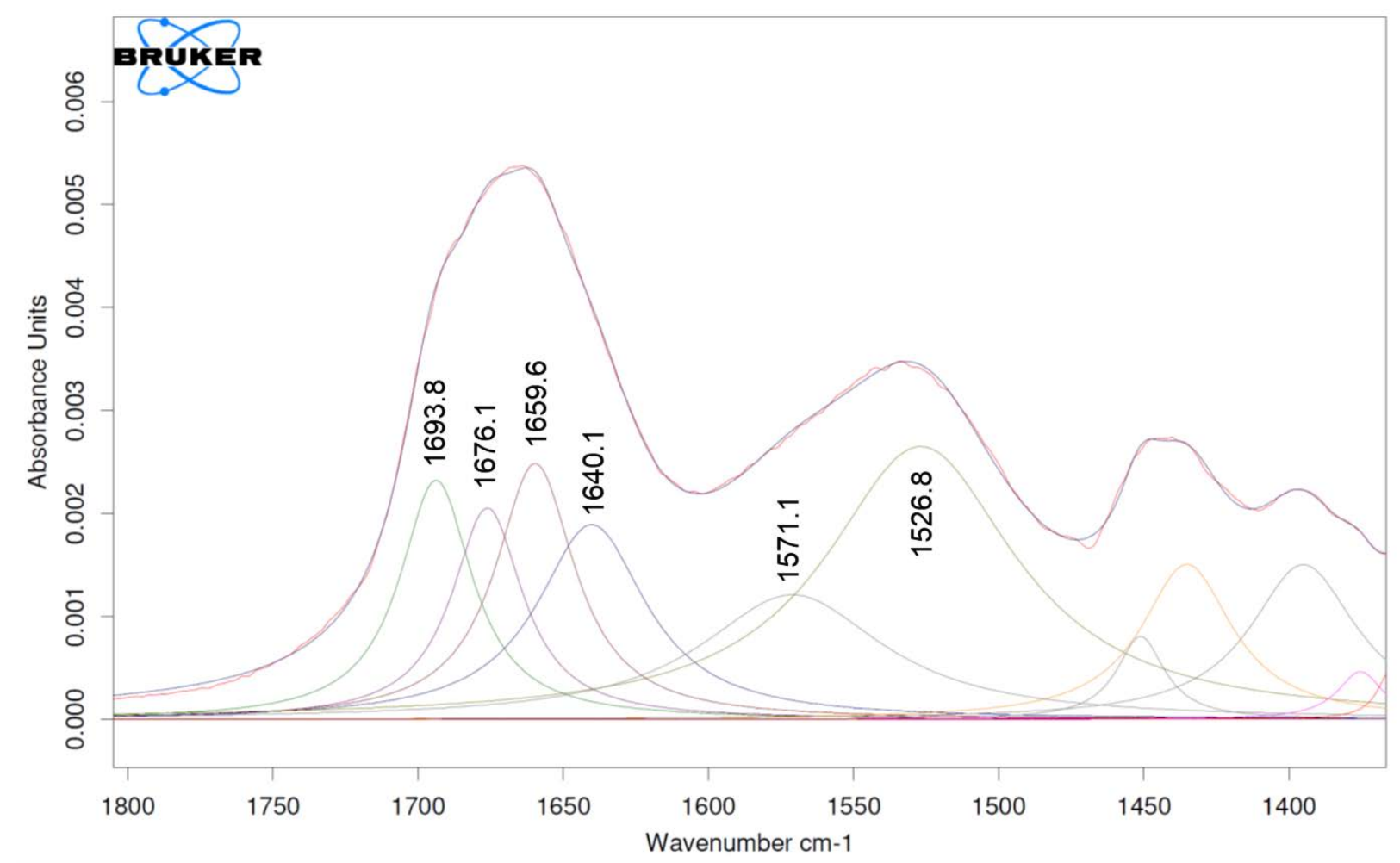

Figure S1. Deconvolution of the amide I and amide II bands of peptide 3, with positions of the subbands indicated in the figure.

Table S1. Amide I and amide II peak positions for the five different peptide SAMs.

\begin{tabular}{|c|l|c|c|}
\hline & Structure & Amide I $\left(\mathrm{cm}^{-1}\right)$ & Amide $I I\left(\mathrm{~cm}^{-1}\right)$ \\
\hline $\mathbf{1}$ & CPPPPSGKGSSGSST & $1671.2 \pm 0.7$ & $1542.3 \pm 0.6$ \\
\hline $\mathbf{2}$ & CPPPPKEKEKEK & $1668.1 \pm 1.1$ & $1543.4 \pm 2.4$ \\
\hline $\mathbf{3}$ & EKEKEKEPPPPC-Am & $1664.3 \pm 0.4$ & $1533.6 \pm 0.1$ \\
\hline $\mathbf{4}$ & CALNNKEKEKEK & $1681.4 \pm 0.1$ & $1541.6 \pm 0.2$ \\
\hline $\mathbf{5}$ & CFGAILSSKEKEKEK & $1670.9 \pm 0.6$ & $1541.4 \pm 1.0$ \\
\hline
\end{tabular}




\section{Stability tests of the peptides}

To ensure that shipment of the samples did not affect the quality of the SAMs, samples for IRAS were packed with a shipment for cyprid barnacle assay (from Linköping, Sweden, to Beaufort, North Carolina, USA), and then returned unopened. IRAS spectra obtained before dispatch, and upon return, are included in Figure S2.

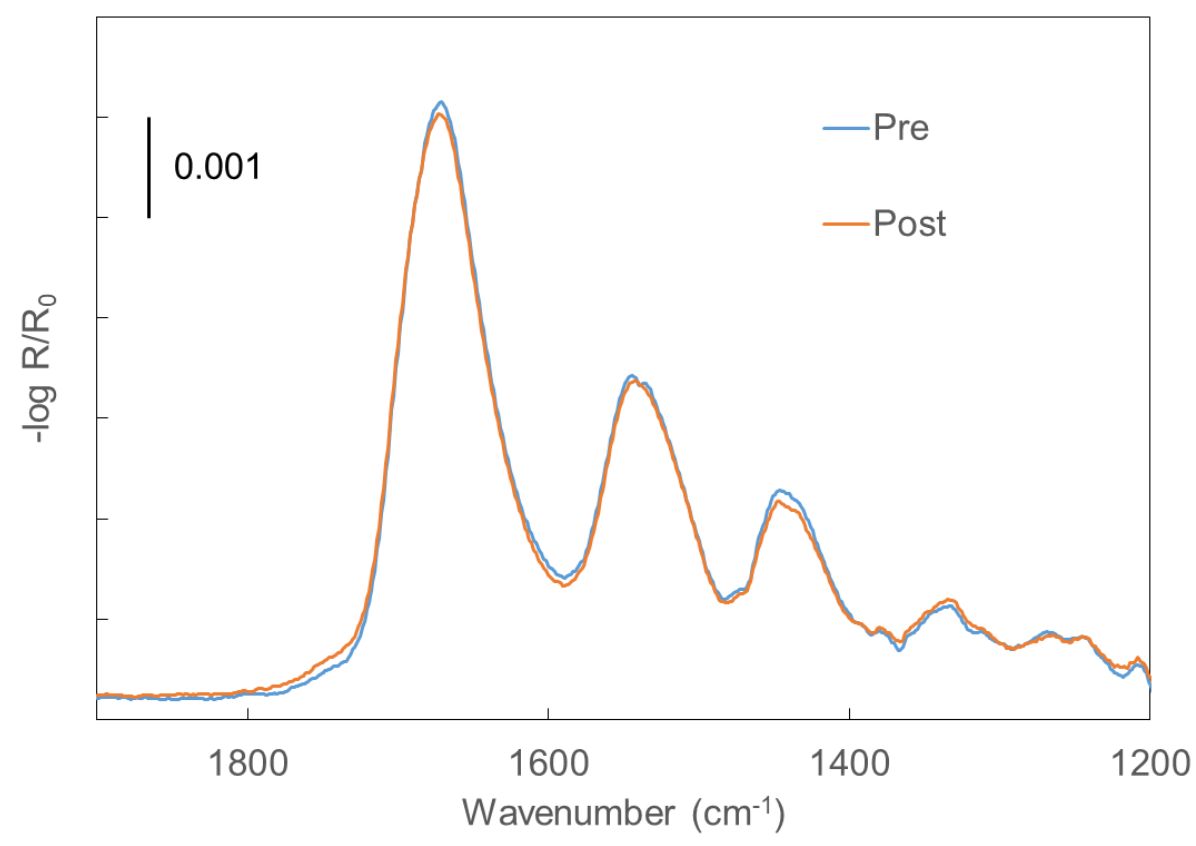

Figure S2. IRAS spectra obtained on a peptide $\mathbf{2}$ sample immediately after preparation, and after a return shipment (under $\mathrm{N}_{2}$ gas) to the site for the cyprid barnacle assay. 


\section{Protein adsorption assays}

Table S2. Adsorbed amount in the protein adsorption assay, converted to mass per unit area. This is data from Figure 3 of the main text, converted from RU units.

\begin{tabular}{ccccc}
\hline & \multicolumn{4}{c}{ Adsorbed amount of protein $\left(\mathrm{ng} / \mathrm{cm}^{2}\right)$} \\
& BSA & Fib & Lys & Pep \\
\hline 1 & 14.1 & 26.5 & 7.0 & 7.8 \\
2 & 4.4 & 19.8 & 7.8 & 14.5 \\
3 & 7.6 & 21.6 & 6.6 & 2.4 \\
4 & 3.6 & 22.8 & 11.2 & 18.1 \\
5 & 6.1 & 20.1 & 8.2 & 10.8 \\
mPEG & 27.9 & 174.0 & 14.3 & 46.3 \\
EG6 & 5.7 & 27.4 & 8.4 & 1.1 \\
C16 & 74.3 & 337.5 & 48.7 & 55.3 \\
\hline
\end{tabular}

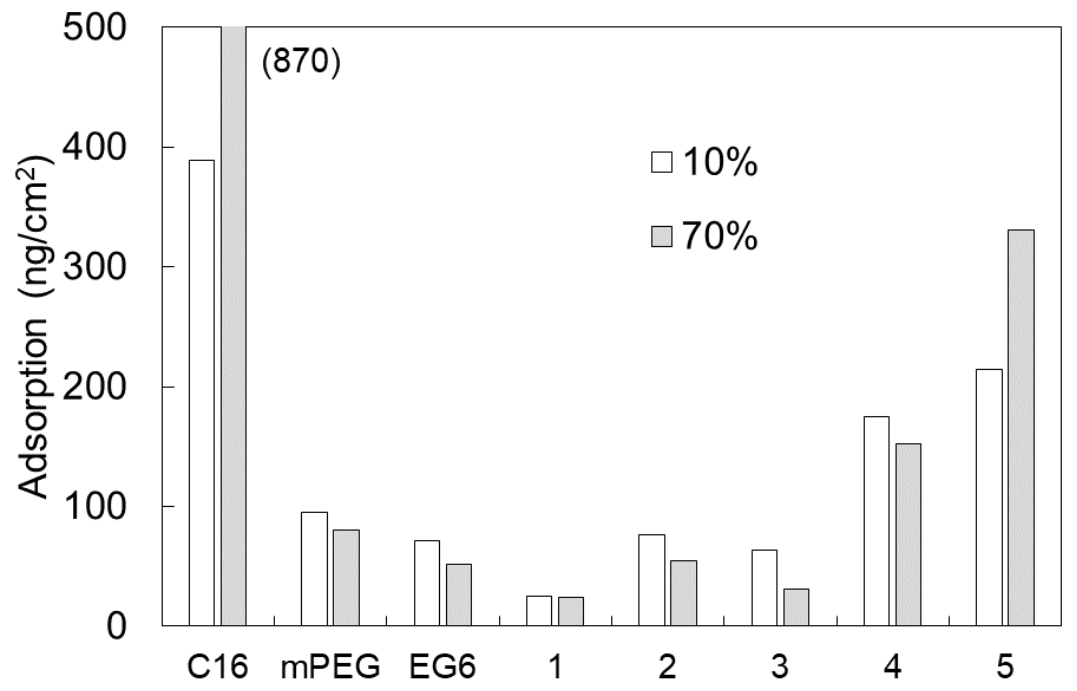

Figure S3. Data for the blood serum assay, shown in units of mass per surface area. This is data from Figure 4 in the main text, converted from RU units. 


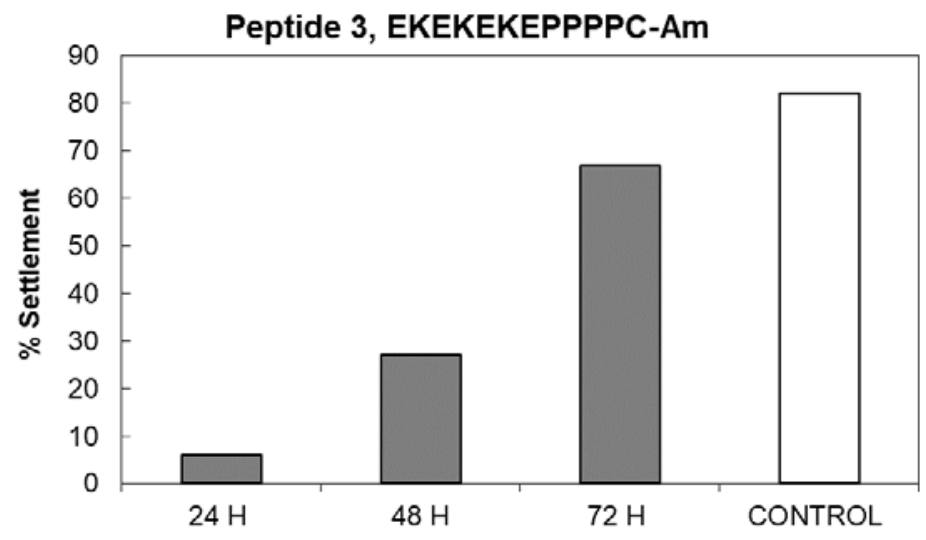

Figure S4. Extended settlement assay on SAMs formed from peptide 3, demonstrating that the low settlement on this SAM is not the result of toxicity, since the cyprids eventually settle also on this SAM. The control is a clean polystyrene well plate, which is routinely used as an internal laboratory standard.

\section{References}

1. Krimm, S., Interpreting Infrared Spectra of Peptides and Proteins. In Infrared Analysis of Peptides and Proteins, American Chemical Society: 1999; Vol. 750, pp 38-53.

2. Haris, P. I., Fourier Transform Infrared Spectroscopic Studies of Peptides: Potentials and Pitfalls. In Infrared Analysis of Peptides and Proteins, American Chemical Society: 1999; Vol. 750, pp 54-95.

3. Goormaghtigh, E.; Ruysschaert, J.-M.; Raussens, V., Evaluation of the Information Content in Infrared Spectra for Protein Secondary Structure Determination. Biophysical Journal 2006, 90 (8), 2946-2957. 